\title{
The Dynamic of Institutional Relation of BPD and Village Head Problems of Local Political Representation
}

\author{
Dina Dwi Rahayu \\ Department of Government Science, \\ Brawijaya University, \\ Malang, Indonesia \\ dinadwi37@gmail.com
}

\author{
Tuhfatul Maula \\ Department of Government Science, \\ Brawijaya University, \\ Malang, Indonesia \\ maulatuhfatul@gmail.com
}

\begin{abstract}
BPD (Badan Permusyawaratan Desa) is a public political representation instituted in the village governance structure. Institutionally, the dynamics relation of BPD and village head have been influenced by the institution of BPD such as Badan Musyawarah Desapraja, Lembaga Musyawarah Desa, BPD (Badan Perwakilan Desa), and BPD (Badan Permusyawaratan Desa). As an institution which serves as a political representation of the village community, the influence of institutional transformation on its political relations with the previous village head has never been done. This research uses case study method with qualitative approach. The focus of this research is on the institutional relations of $B P D$ and the village head in Wonomulyo Village, Poncokusumo Sub District, Malang District. The theoretical framework which the authors uses in this research is Historical Institutionalism and the concept of executive relations by Hanta Yudha. The confrontational relationship has occurred due to the personal head of the village and BPD in Wonomulyo were strong while the institutional system between them was weak.
\end{abstract}

Keywords: institutional relation; political representation; village government

\section{INTRODUCTION}

This research is a case study on the dynamics of institutional relations of BPD and village head. After New Order era, democratization opened widely and implemented with a reckless which has caused the dynamic between BPD and village head tapered. Previously, during the New Order regime, a similar institution of BPD was established under the name of the Lembaga Masyarakat Desa (LMD), but in line with the collapse of the New Order regime, the LMD institution became a BPD and its membership was directly elected by the people. This is why the authority of BPD as a new institution in the village has the potentials to generate dualism of power and create a confrontational relationship between BPD and village head.

The need to establish a BPD is a form of state penetration of the village regardless of the historical sociocultural conditions of the village. The concept is still the same as the state driven development [1]. As we know, the practice of these concepts and approaches has destroyed the village as a sovereign local entity. The state's behavior toward the village could be traced through several thoughts such as the work of Mochtar Mas'oed [2], highlighting the state bureaucracy that enters into the village by giving birth to state corporatist organizations, such as Pembinaan Kesejateraan Keluarga (PKK), Karang Taruna and RT/RW [2].

The same is also written by Hans Antlöv which reflects the role of state domination in village life in his book "Negara dalam Desa" [3]. In fact, the book of Yando Zakaria expressed that the village's helpless situation being diluted by the state. The village was always a locus and the focus of the state was to launch development actions, as Sutoro Eko often referred to, the village became the project market and only as superintendent staff [4].

This has led to the politics of representation introduced by the state to the village not always well received, even tending to create new problems in many villages. The problems between the institutional relations of BPD and the village head then gave birth to Law 32 of 2004 which aims to cure conflict in the village between BPD and village head. Basically, the constitution actually cuts the duties and functions of BPD which makes village's democracy back nuances with heavy executives. Therefore, it emerged Village Law 6 of 2014 which is a state effort to change the paradigm of the village and change the institutional relations of BPD and village head. With full awareness of the Village Law, it emphasizes the presence of a hybrid model, namely a self-governing community and local self-government. [4] Through this law, the state has sought to correct its behavior against the village, making the village as a communal entity granted autonomy to take care of its own household and run its own political system.

After the confrontational relation of BPD and village head, the BPD is a village discussions committee whose membership is chosen based on the village people and determined by the village head. This is in accordance with the Village Law which provides affirmation of the institutional position of BPD, parallel to the Village Head according to the principle of separation of powers. The BPD is as the village legislature and the village head as executives, but under the actual conditions of village governance remains dominated by the executive role as central ruler. The institutional issues of BPD and the village

Corresponding author: Dina Dwi Rahayu 
head in this paper are traced through an analytical approach to the theory of historical institutionalism.

\section{RESEARCH METHOD}

The research in this case study uses a qualitative method. Instruments used in data collection include interviews, literature studies, and documentation. The focus of the research in this paper is the institutional transformation of BPD as a form of political representation of village communities and the dynamics of relations between the BPD and the village head.

\section{A. Historical Institutionalism Theory}

In the analysis of the dynamic relation of BPD and the village head, the authors use the theory of historical institutionalism as suggested by Guy Peter [5] Historical institutionalists see institutions as continuity. As they point out, institutions are meant to be a tool that can preserve a culture or policy. Path dependency emphasis is another way of saying that reforming an institution always requires very high transaction costs, although extreme conditions can reduce the cost of marginal change. In the beginning, historical institutionalism focused on institutional development and changes consisting of exogenous analytical tools (critical juncture and path dependences).

\section{a. Path dependency}

The basic idea of Historical Institutionalism is that a policy begins when the institution is established, or when it is initiated, then traces how influential it is in the future to the present. This is known as path dependency; when government or organizational policies begin to run they will tend to remain unchanged and as they were at the outset. Although it has changed little, the change requires political conditions that can drive change itself. [5]

\section{b. Critical juncture}

Another way to explain changes by historical institutionalism is through understanding the critical juncture idea. Critical juncture can be seen from how individuals within the institution do not want any change despite a constellation of internal political force. Collier defines critical juncture as a period of significant change that occurs differently in different regions and produces different laws. [6] A large and enduring regime for a long time can lead to stagnation in its institutions. Unless this stagnation can change if within the internal is able to form the power of political movement together. That is, a political movement of change in that stagnant will not be able to change if the powers of change are built individually. Critical Juncture, if described in a case, will be as though there are new provisions related to the function of village legislation from the central government, there is a tendency that remains and does not change even though there is a legal encouragement through the law.

\section{B. Executive and Legislative Relations Concept}

Firstly, effective relation is a condition where both institutional and non-institutional aspects are strong. Secondly, the accommodative relationship is a condition where the institutional aspects are solid, but the noninstitutional aspects are weak. Thirdly, confrontational relations are conditions when the institutional aspects (construction, the design of political institutions and party systems) are still fragile but the personality and style of executive leadership is strong. Fourthly, reductive relation is weak institutional condition and supported by an executive's person is also weak. The weak personal condition, the constitution, the construction and the weak system of the executive and legislature then make the control of the legislature very strong. [7]

\section{RESULT AND DISCUSSION}

\section{A. Historical Institutionalism Analysis in the Dynamics of Relation of BPD and Head of Wonomulyo Village}

As a form of explanation of the continuity of BPD institutional formation the author will explain the historical process of the BPD. As historical institutionalism researchers do, institutions are meant to be a tool that can preserve a culture or policy. Path dependency emphasis is another way of saying that in making changes within an institution it is necessary to reform. Historical institutionalism focuses on institutional development and change consisting of exogenous analytical tools (critical juncture and path dependences).

\section{B. Path Dependency on Institutional Arrangement and Transformation of BPD in Village Government \\ 1. Village in the Old Order}

The relationship between the village head and the Deliberation Council of Desapraja in the Soekarno era was experiencing an accommodative relationship. It can be said to be accommodative because of the position of the village head that is still very strong during this regime. The strong position of the village head is due to the lack of construction and the constitution which governs the Deliberation Council on the other side of the village personnel personally very strong. The strong personality of the village head was due to the past construction of the village head that has existed since before the colonial era so that a village head would tend to have a strong personal character. In addition, the Deliberation Council of Desapraja was a new institution whose authority was not set and explicitly regulated which made this institution only as a formality.

\section{Village Society Institutions in the New Order Period}

Article 3 of Law 5 of 1979 states that the village government consists of village head and Lembaga Musyawarah Desa (LMD), which was a deliberative or consensus institution between the village government elites and village community leaders. [8] In the period of the politically repressive New Order regime to support 
'economic development', the village's economic activities were dragged into the vortex of sectorial modernization. This policy had an emphasis on making it easier for the central government in terms of "control". The relationship between the village head and the LMD during the New Order period tended to be stable and not dynamic. The relationship between the LMD and the village head was likely to be stable and assumed because the LMD membership was still part of the village chief's choice. Thus, village governance was still dominated by local elites who were still in the same compromising class.

The existence of LMD as an institution that became the representation of society in village government became indicated ineffective. The meaning of village, which merely as an administrative concept that put the village under the sub-district structure, had been mentioned above that the village is not a territorial unity. The existence of LMD seemed like a political project because although it was a textual representative of the community, but in fact this institution made the village government only controlled by the elite. Supported by the tasks, principal and function as stated in Law 5/1979 stipulating that the village head and the LMD were responsible to supra village officials, not to the community. The village became like a bureaucratic machine that only became an extension of the power of central government.

\section{BPD at the Beginning of Reform}

The presence of Law 22/1999 on Regional Government has given a new color in the administration of village government. This change brought a new paradigm in viewing the democratization of the village. This law is considered to contribute positively to the progress of village governance. In particular, the presence of new institutions at the village level as an effort in realizing the government of the people, by the people and for the people. One of the new institutions is the BPD which is textually representative of the community directly elected by the community as well.

Law 22/1999 affirms that BPD is an institution parallel to the village head and has the right to appoint village heads. The village head may also be dismissed by the regent on the proposal of BPD. Although BPD and village head are equal, the BPD's stronger authority has made BPD impressed the higher institution of the village head. The existence of BPD has been also full of harmony with the Village Head.

Post-Soeharto era can be identified that the state has made a policy which was a policy of uniform form. Village obligations formed an institution called BPD as an effort to decentralize power and village autonomy efforts. In fact, this policy tended to be forced because not all villages were ready with this kind of democracy model. Villagers are people who are comfortable solving problems by way of village meetings or customary deliberations. The relation that existed in the early days of reform in Wonomulyo was the confrontational relationship. Confrontational conditions were due to a strong personal head of the village but not accompanied by a strong support of the village head. On the other hand, BPD played a strong role and performs its function predominantly over the village head. BPD played a very arrogant role and weakened the village head.

C. Critical juncture on the relationship of BPD and Village Head through UU No. 22 of 1999

According to the explanation of historical institutionalism, critical junctures are major events affecting the political and economic balance that exist in one or many communities. In the political history of the village of Wonomulo, there are several events which could be used as a sign of the critical juncture of the institution of BPD. Critical juncture on changes to BPD could be marked with some events: a) Reforms that gave birth to Law 22/1999; b) The presence of Law 32/2004 that BPD is no longer a representative but a deliberation.

The pattern of the relationship between BPD and the village head that occurred during the new order in Wonomulyo was an accommodative relation. This was because considering that LMD was a member of the community of representatives of the elected group based on the decision of the village head. LMD and village head could be said to be two institutions which come from one understanding and same ideology. Relations both are very accommodative and even the mechanism of controlling could not run effectively. The ineffectiveness of the institution was due to the LMD's ideology and the same with the village head as two compromise institutions. Thus, the LMD that should be the representative of the village community in the governance structure is incapable of performing its functions properly. The political state of the village was vulnerable to oligarch power.

This is although not a democracy system that textually applied Indonesia, in fact still happen. These conditions made the Indonesian society inadvertently then demand a new regulation that is more just and equitable. The point of change (critical juncture) is called a period of reform that could be marked by the collapse of the Soeharto regime.

Law 22/1999 is a rule which contributed greatly to the history of BPD in Wonomulyo. At this time, BPD institutions that have the main idea of representatives of village communities are elected by general election. This election procedure is the same as the way the village head electorates. Terms used in the nomination of BPD is the same as the election requirements of village head. This rule brings a major change in the history of the politics of Wonomulyo Village. The significant change was the idea of community representatives in the village government structure previously elected by deliberative voting then according to the law was elected by the community directly. It makes new assumptions about BPD and village heads that could be said of the dualism of power.

The next important issue is the internal consolidation of BPD so that the institution could maximize its role. The root 
of the problem is great authority of BPD's power. It may propose to the regent on the dismissal of the village head. In Wonomulyo Village, it encourages the politicization of BPD institutions by its chairman. This psychologically leads to displeasure and provokes a rejection reaction by the village head. The conflict then dragged on the difference in interpretation of the role of "supervision" held by BPD. BPD tends not only to oversee but progresses to the performance of the village head.

In the village of Wonomulyo, from the beginning BPD formed the nuances of the politicization of the institution obviously. The position of the BPD which should be the complement of the Village Head in running the village government is deviated from the "Head" of the village head. BPD tends to perform its role in an over capacity. The problem could be seen clearly because it related to the implementation of the development program is the authority of the village head, the BPD should have the authority to provide opinions and inputs. Supervision that does not lead to undue loss of the village is then exaggerated by BPD, exceptionally if there is any misuse in the field of implementation of village regulations and village budgets. Research in Wonomulyo Village during the early establishment of BPD justified the assumption that the politicization of BPD's political elites has reduced the effectiveness of the institution in carrying out an effective "oversight" function.

\section{CONCLUSION}

The conclusions drawn from the case studies in this journal are, firstly, In the institutional transformation BPD authors found the main idea of formation of BPD is a form of political representation on the village scale.

Secondly, The BPD and the Village Head will experience a conservative relationship if there is a different platform between the Village Head and the BPD while the institutional aspect between the two is weak.
Lastly, the relationship pattern of BPD and the Village Head in general is effective but due to the regulations that make an individual able to overpower make BPD tend to act over capacity. This difference in the pattern of relations is due to the contribution of the regime change that made the reforms to the village administration.

\section{REFERENCES}

[1] S. Zamroni, The Potrait of Politic and Local Economy in Indonesia (Potret Politik dan Ekonomi Lokal di Indonesia), Yogyakarta: IRE, 2017.

[2] M. Mas'oed, Politic, Beraucracy, and Development (Politik, Birokrasi dan Pembangunan)., Yogyakarta: Pustaka Pelajar, 1994.

[3] H. Antlov, A Country in a Vilage : Patronage the local Leadership (Negara dalam Desa; Patronase Kepemimpinan Lokal), Yogyakarta: Lappera Pustaka Utama, 2002 .

[4] B. K. Sutoro Eko, Local Institution thorough Rural Area Development (Institusi Lokal dalam Pembangunan Perdesaan), Jakarta: Bappenas, 2012.

[5] G. Peters, Institutional Theory in Political Science: The 'New Institutionalism', London: Continumm, 1999.

[6] R. B. Collier and D. Collier, "Critical Junctures and Historical Legacies," in Shaping The Political Arena: Critical Juncture, The Labor Movement, and Regime Dynamics of Latin America, Princeton, Princeton University Press, 1991, pp. 27-39.

[7] H. Yudha, Half-hearted Presidentialism (Presidensialisme Setengah Hati), Jakarta: Gramedia Pustaka Utama., 2010.

[8] I. H. Gayatri, Local Democracy in Village; Quo Vadis (Demokrasi Lokal di Desa: Quo Vadis?,) The Interseksi Foundation, Jakarta, 2010 . 